\title{
«La primera portada celestinesca sevillana: estudio de una parodia iconográfica e iconológica»
}

Ana Milagros Jiménez Ruiz

Universidad de Zaragoza

Congreso Virtual CELPYC

4 y 5 de junio de 2020 
Este trabajo se ha realizado en el marco del Proyecto de Investigación FFI201675396-P «Catálogo de obras medievales impresas en castellano (1475-1601): nuevas investigaciones», concedido por el Ministerio de Economía y Competitividad.

Para más información, puede consultarse en: www.comedic.unizar.es

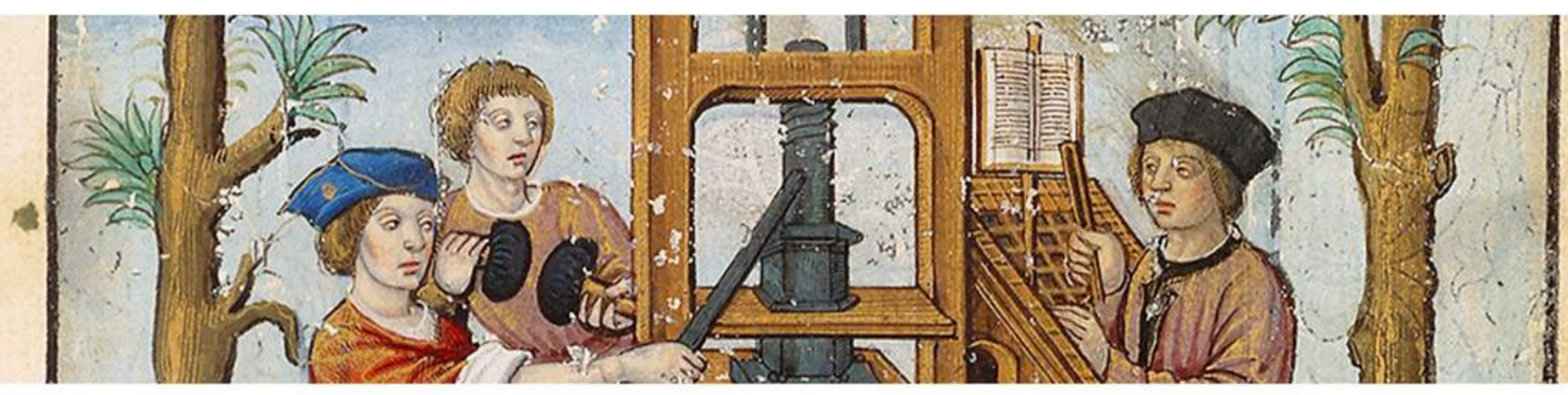




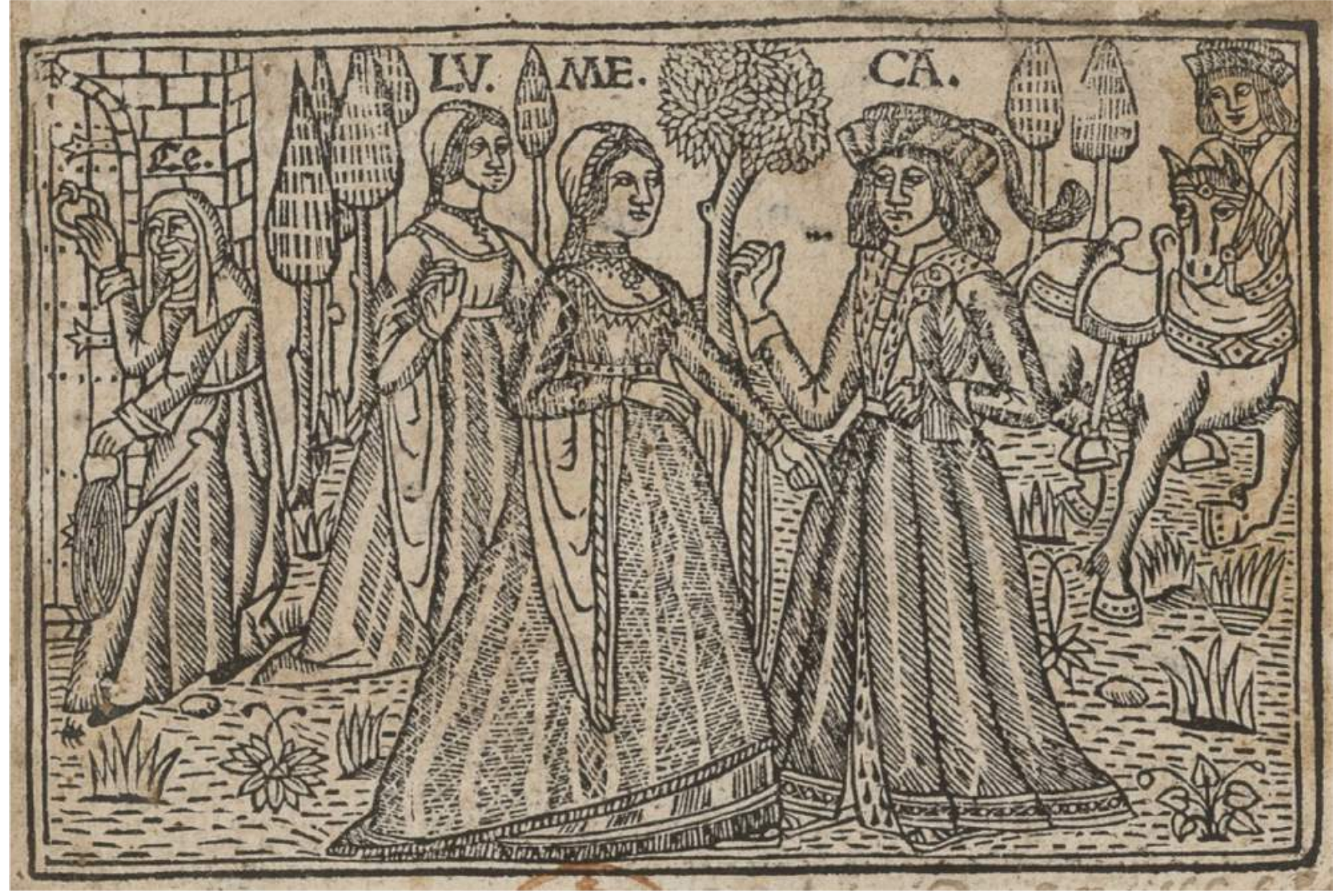

\section{Portada. Sevilla: Estanislao Polono, 1501}




\section{Contextualización metodológica}

- Biblioiconografía o Textual iconography:

- Mercedes Fernández Valladares (2012; 2020 en prensa).

- Estudios sobre la iconografía de la gestualidad e iconología:

- François Garnier (1982) y Jean-Claude Schmitt (1990).

- Erwin Panofsky (1972), Rafael García Mahíques (2008).

- Cesare Ripa (1987 [1593]). 


\section{Repercusión editorial de la edición Sevilla (1501)}

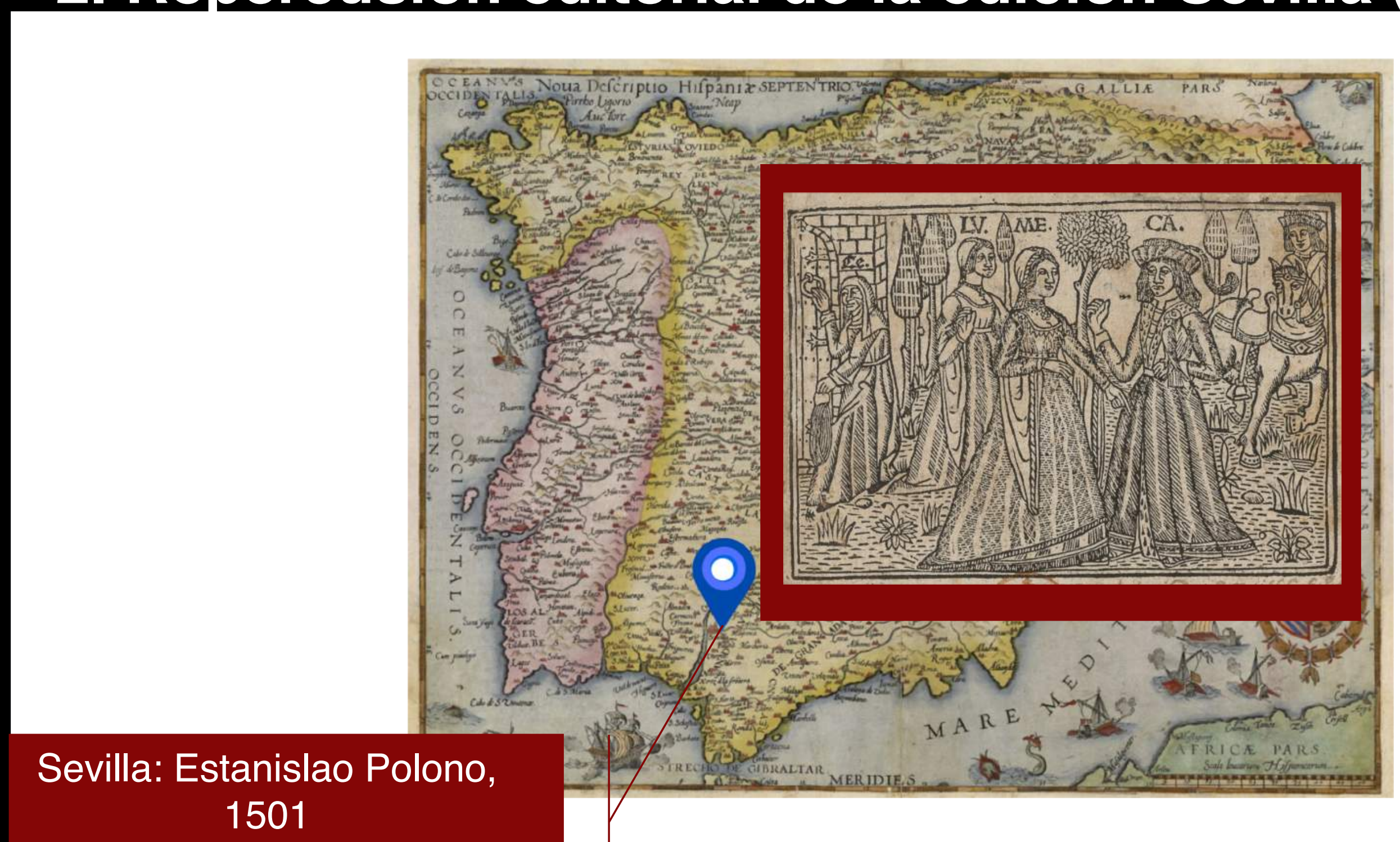

Vid. "La Celestina", COMEDIC: Catálogo de obras medievales impresas en castellano hasta 1600. En línea https://comedic.unizar.es/index/read/id/322 


\section{Repercusión editorial de la edición Sevilla (1501)}

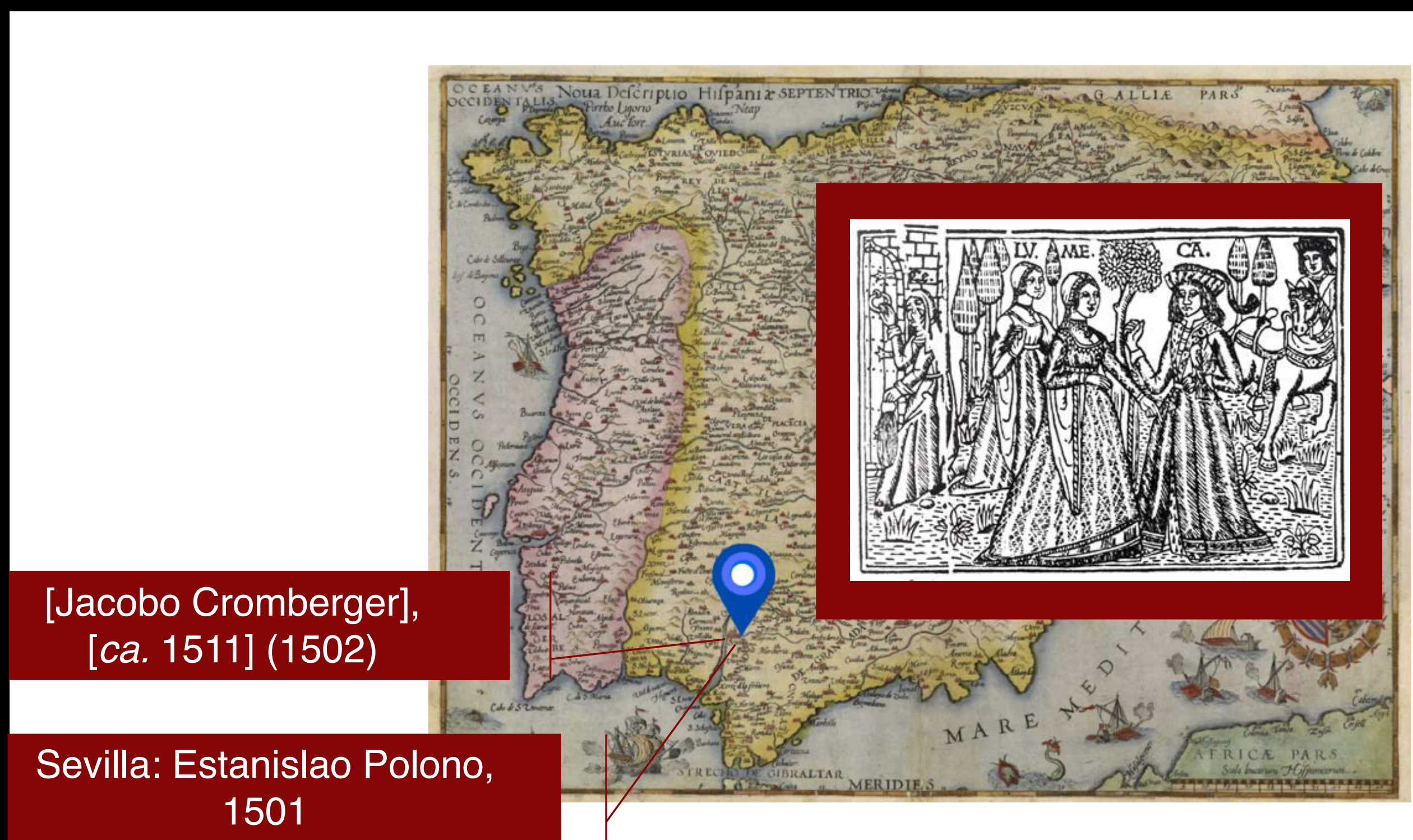

Vid. "La Celestina", COMEDIC: Catálogo de obras medievales impresas en castellano hasta 1600. En línea https://comedic.unizar.es/index/read/id/322 


\section{Repercusión editorial de la edición Sevilla (1501)}

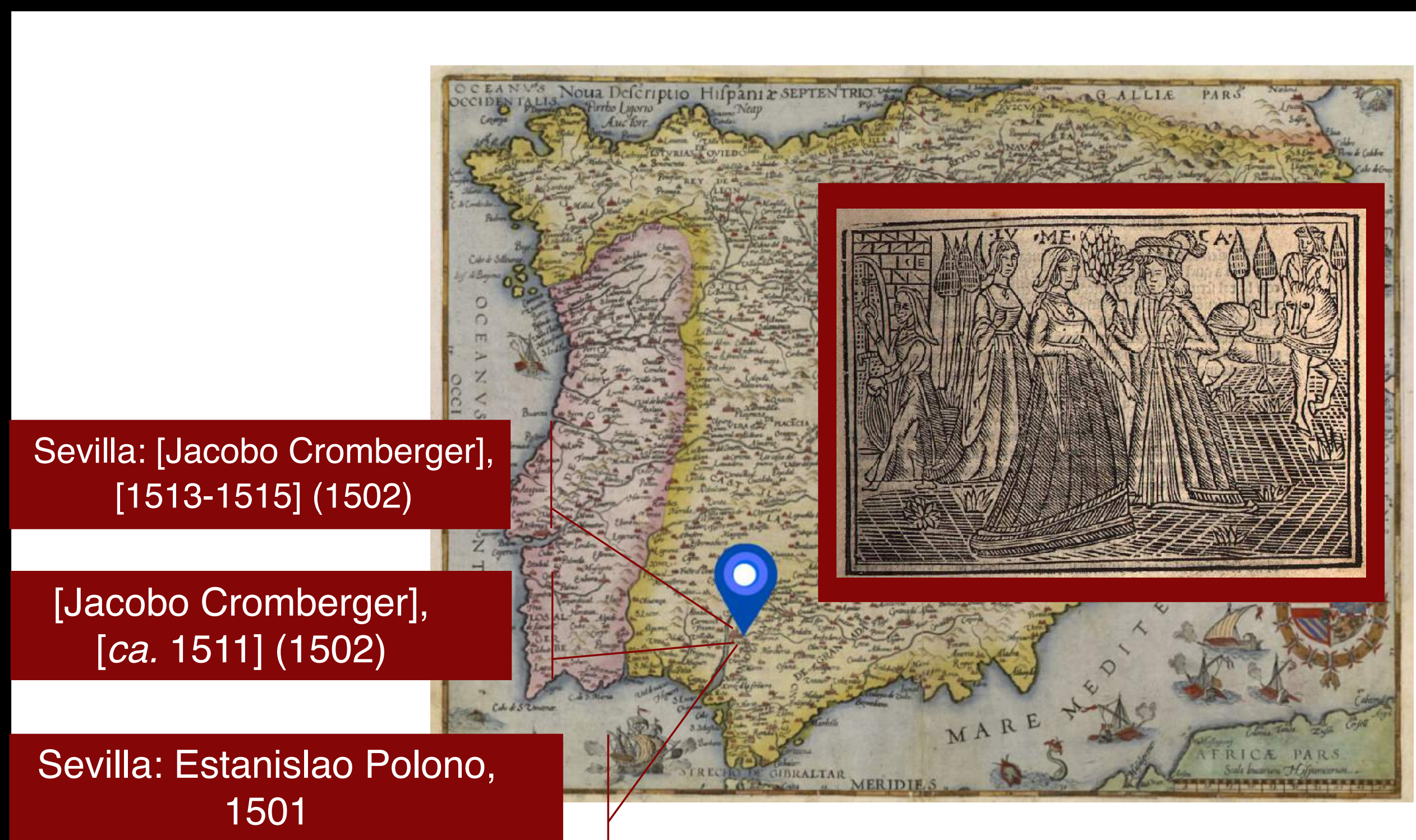

Vid. "La Celestina", COMEDIC: Catálogo de obras medievales impresas en castellano hasta 1600. En línea https://comedic.unizar.es/index/read/id/322 


\section{Repercusión editorial de la edición Sevilla (1501)}

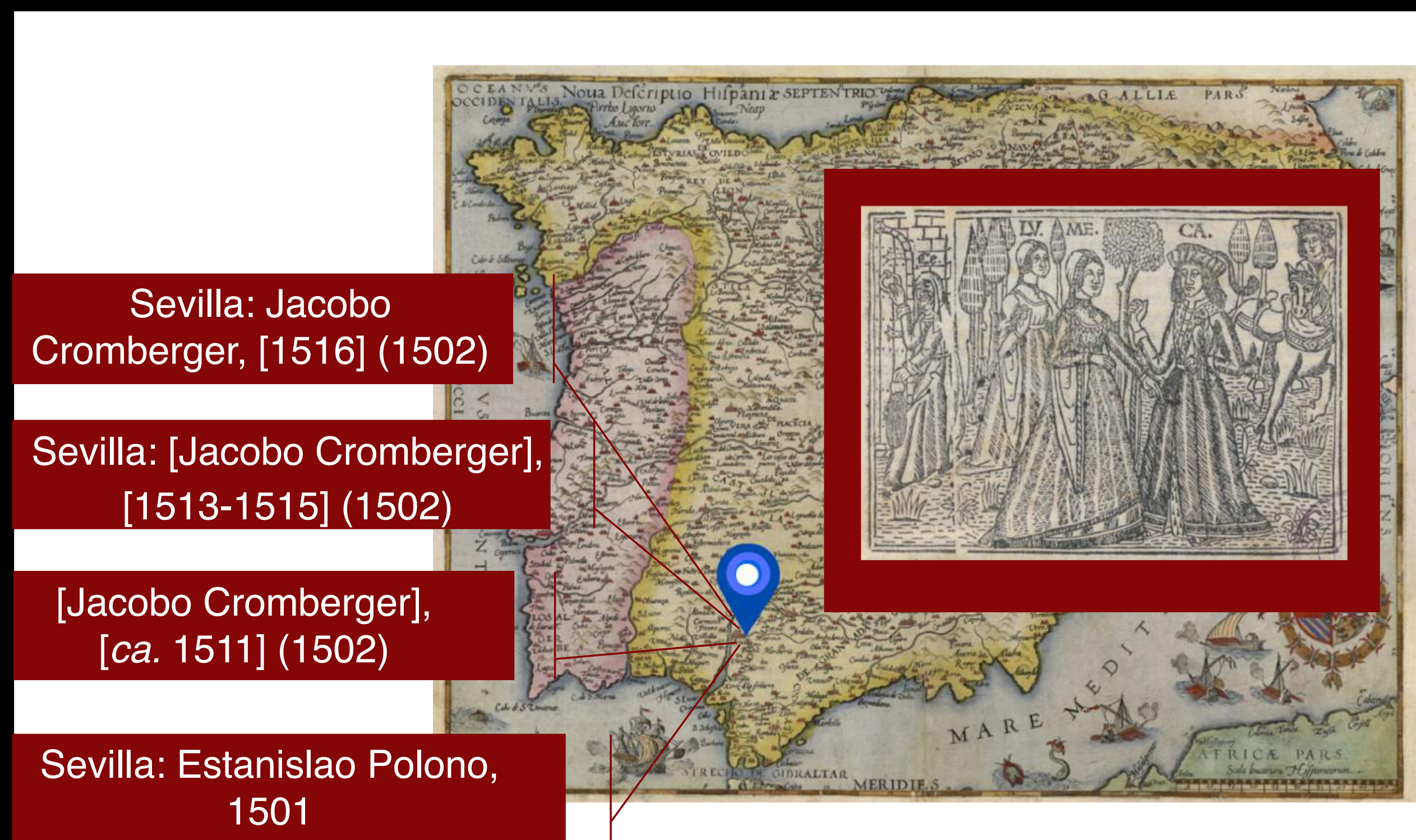

Vid. "La Celestina", COMEDIC: Catálogo de obras medievales impresas en castellano hasta 1600. En línea https://comedic.unizar.es/index/read/id/322 


\section{Repercusión editorial de la edición Sevilla (1501)}

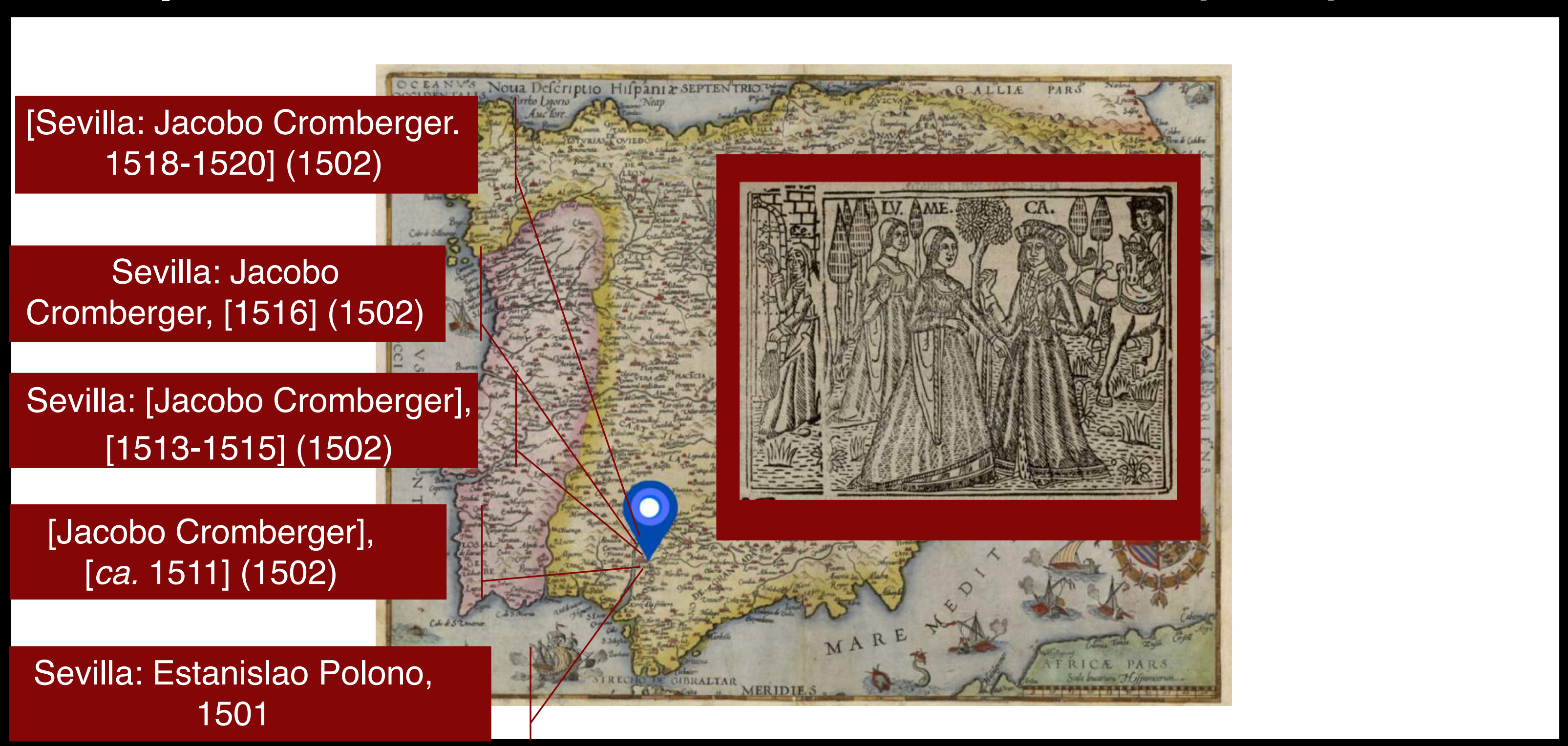

Vid. "La Celestina", COMEDIC: Catálogo de obras medievales impresas en castellano hasta 1600. En línea https://comedic.unizar.es/index/read/id/322 


\section{Repercusión editorial de la edición Sevilla (1501)}

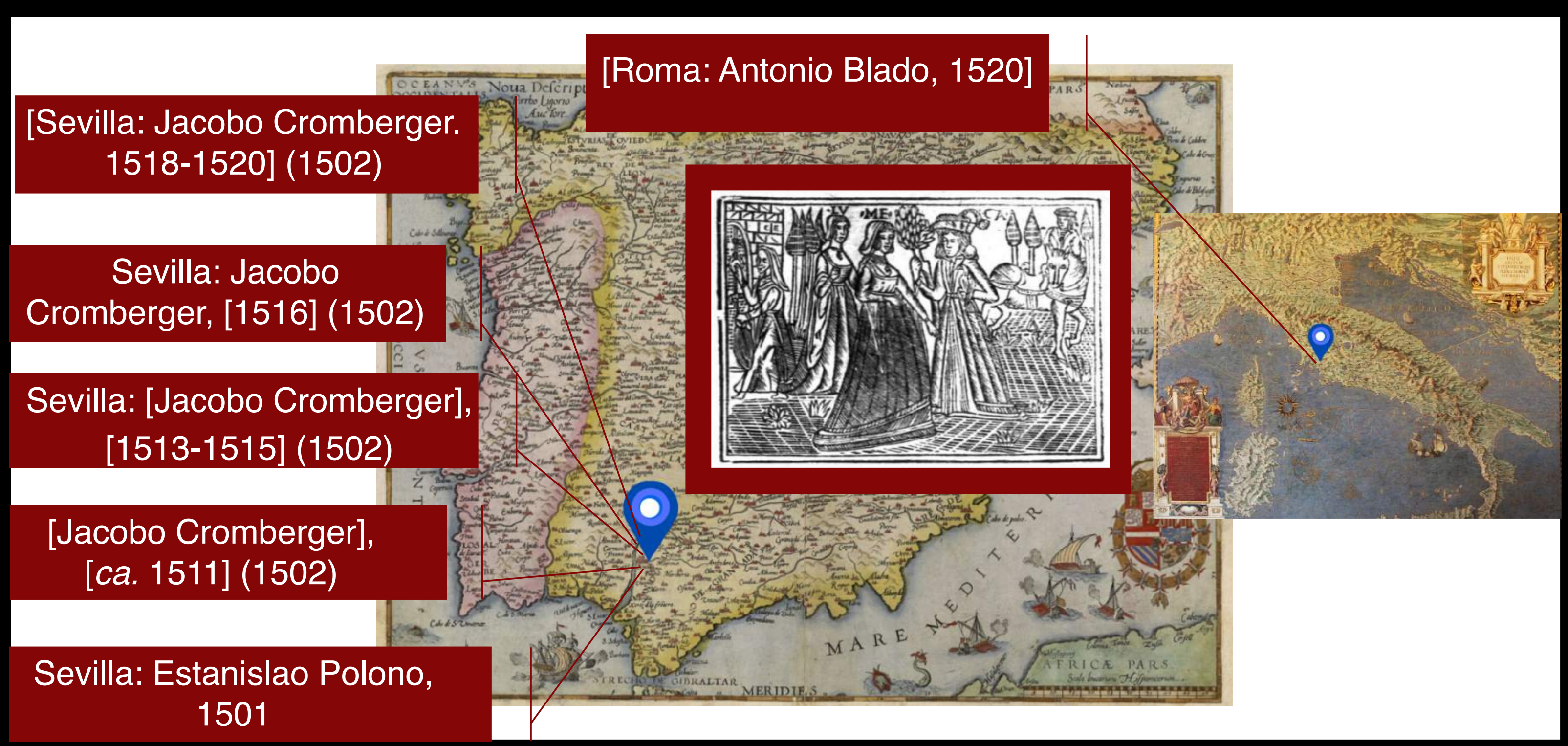

Vid. "La Celestina", COMEDIC: Catálogo de obras medievales impresas en castellano hasta 1600. En línea https://comedic.unizar.es/index/read/id/322 


\section{Repercusión editorial de la edición Sevilla (1501)}

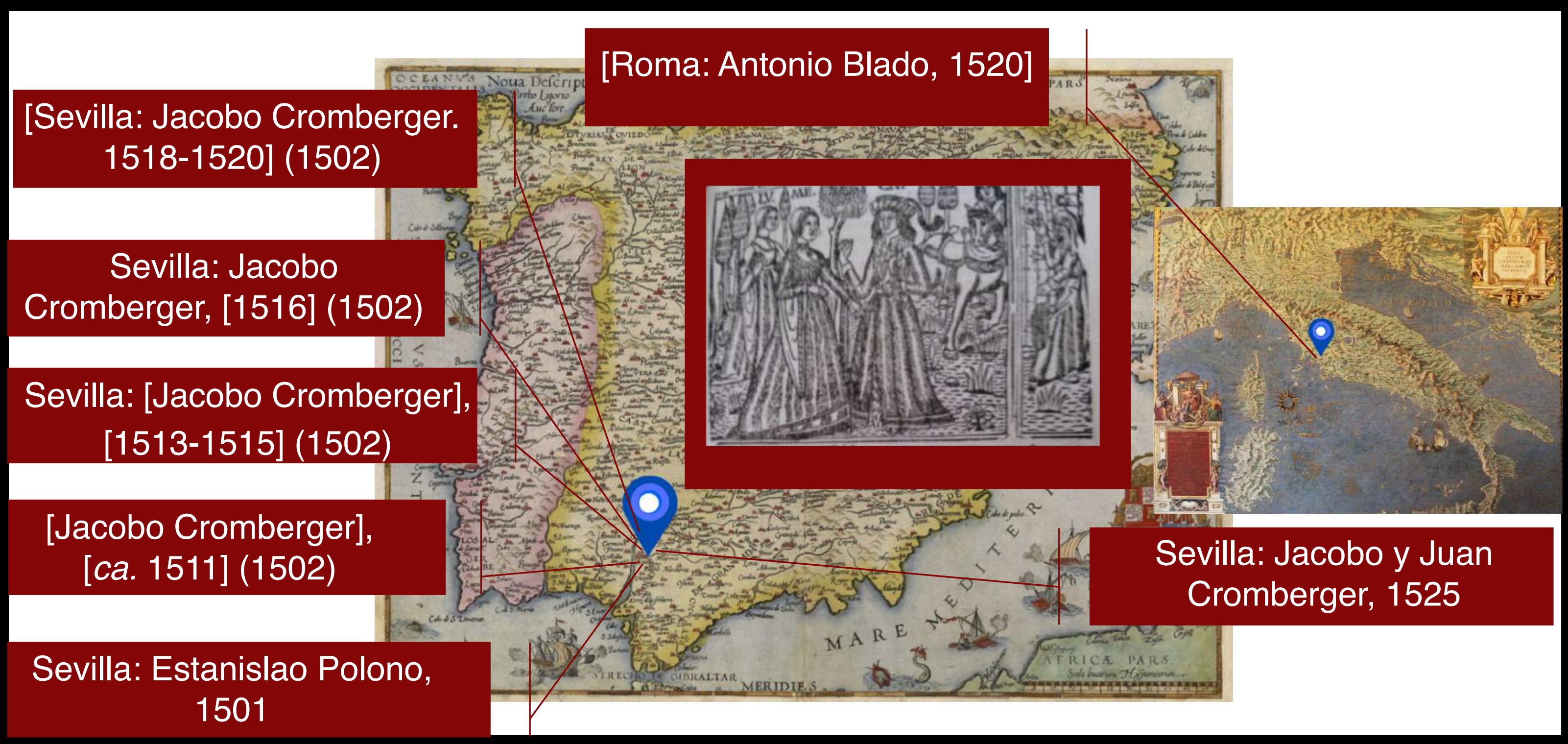

Vid. "La Celestina", COMEDIC: Catálogo de obras medievales impresas en castellano hasta 1600. En línea https://comedic.unizar.es/index/read/id/322 


\section{Repercusión editorial de la edición Sevilla (1501)}

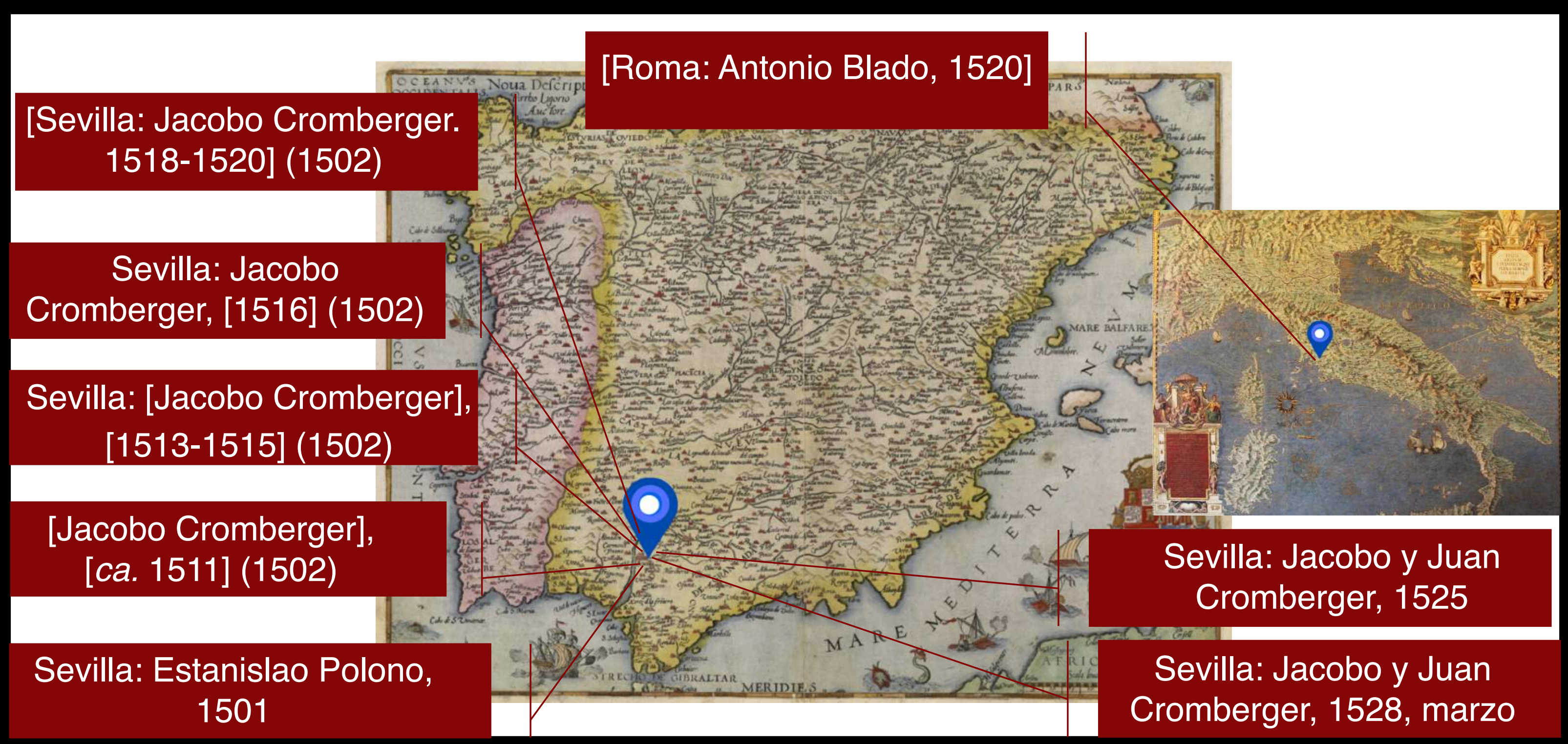

Vid. "La Celestina", COMEDIC: Catálogo de obras medievales impresas en castellano hasta 1600. En línea https://comedic.unizar.es/index/read/id/322 


\section{Análisis iconográfico de la portada (Sevilla, 1501)}

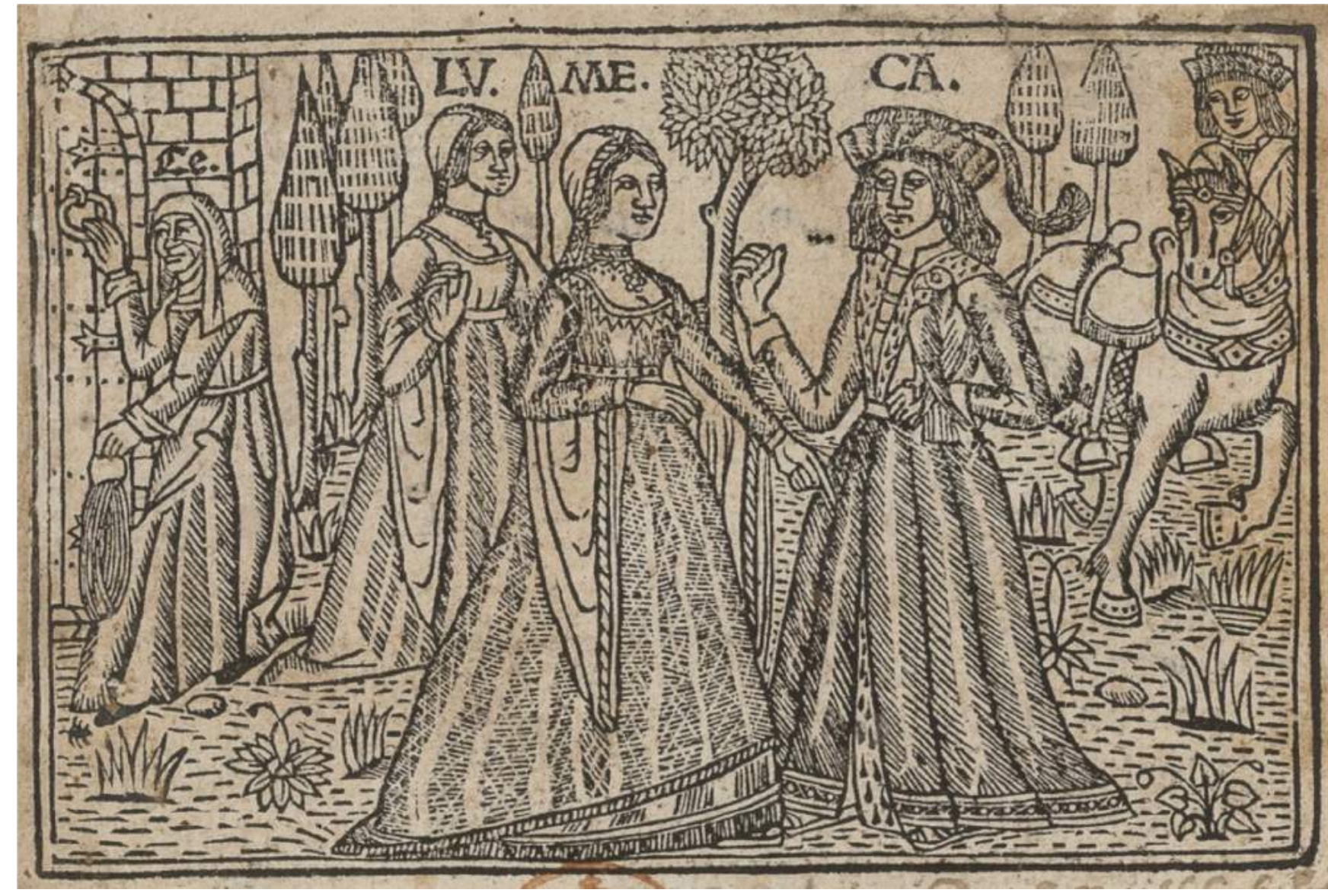

Sevilla: Estanislao Polono, 1501 


\section{Análisis iconográfico de la portada (Sevilla, 1501)}
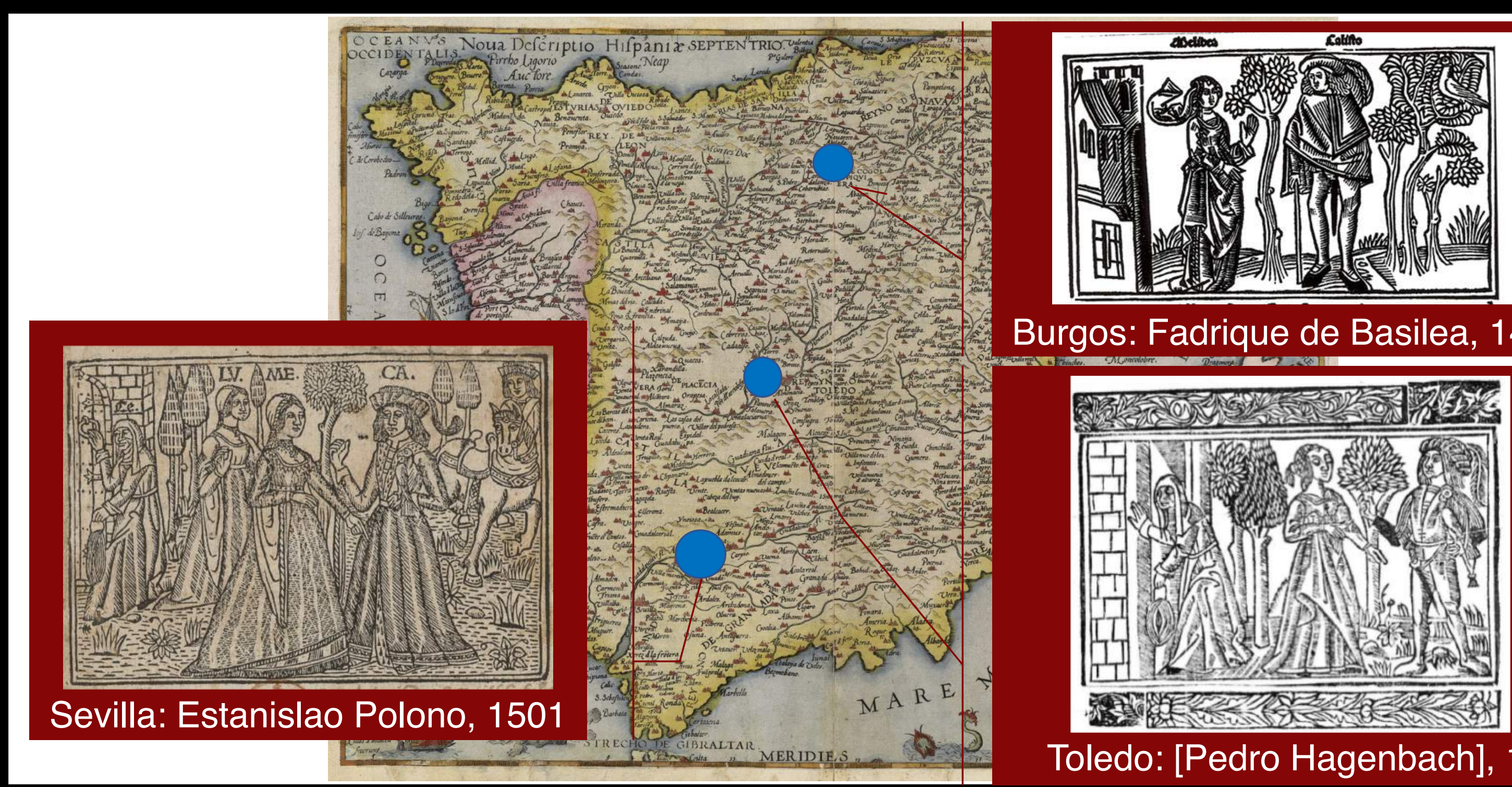

Burgos: Fadrique de Basilea, 1499?

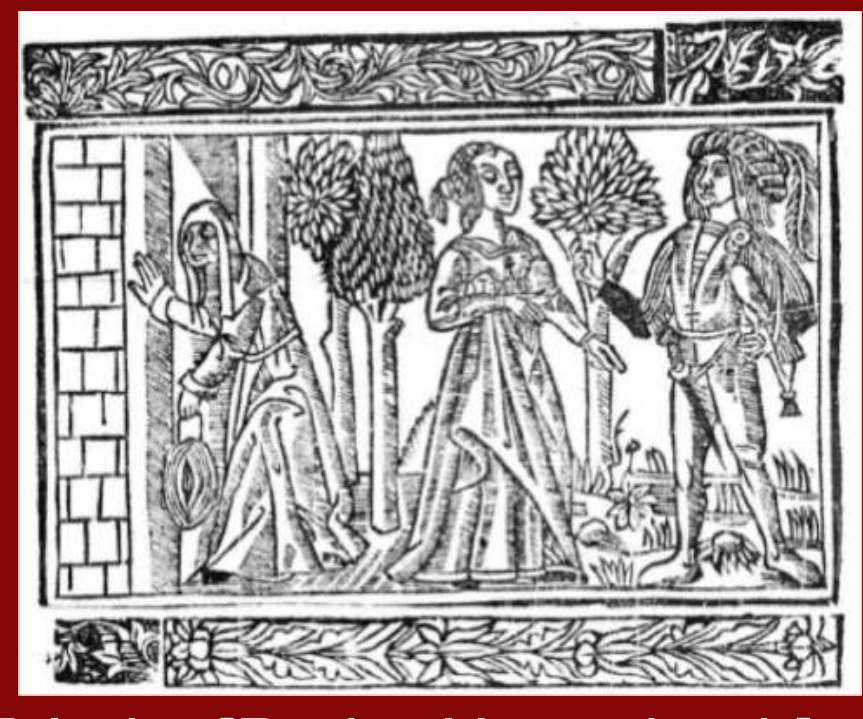

Toledo: [Pedro Hagenbach], 1500 


\section{Análisis iconográfico de la portada (Sevilla, 1501)}

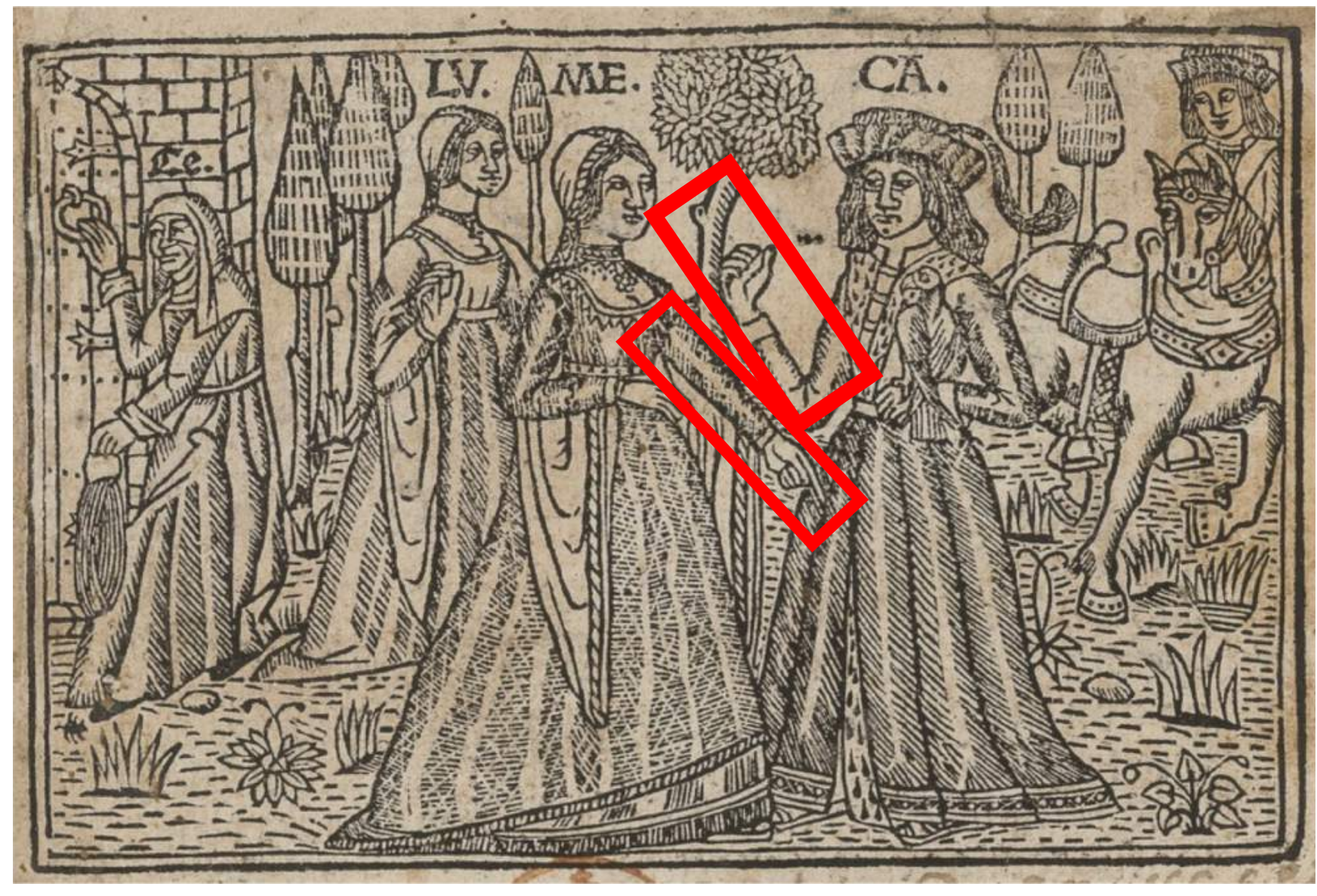

Sevilla: Estanislao Polono, 1501 


\section{Análisis iconográfico de la portada (Sevilla, 1501)}

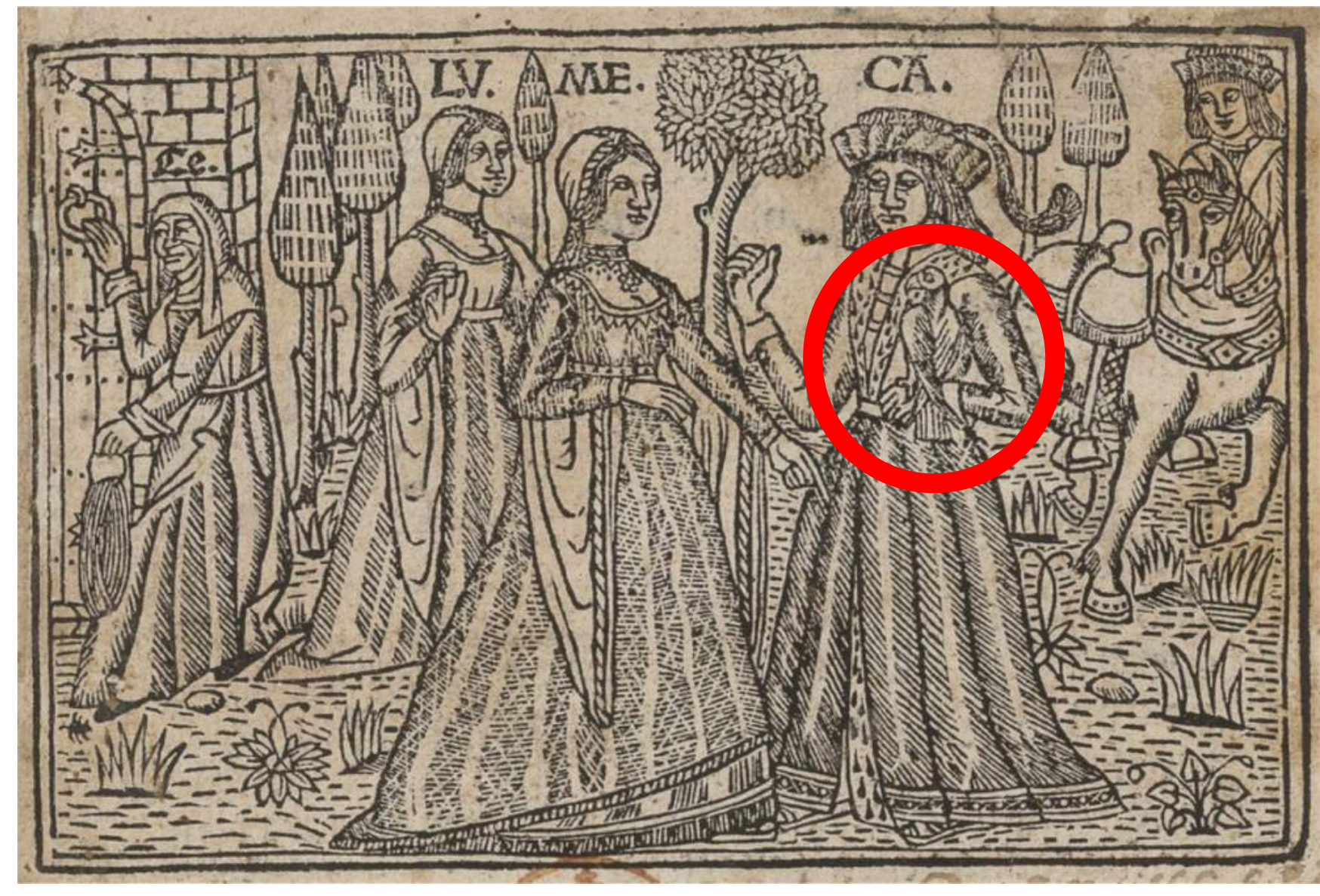

Sevilla: Estanislao Polono, 1501 


\section{Análisis iconográfico de la portada (Sevilla, 1501)}

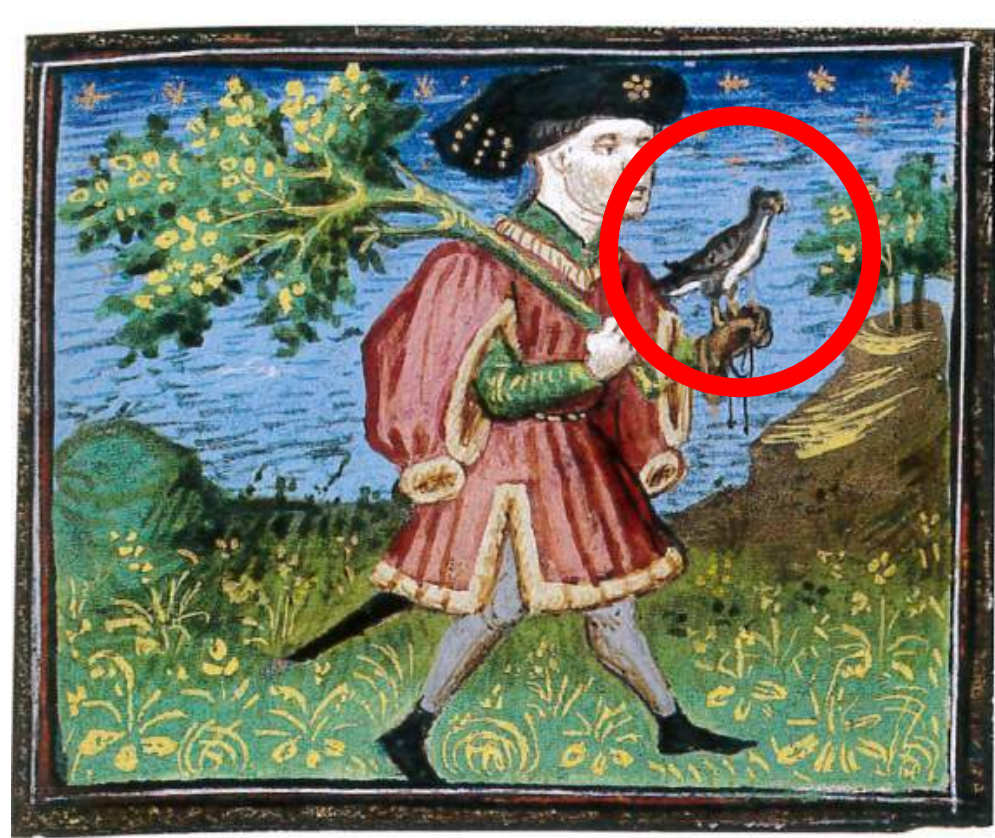

Ms 31834, fol. 6 (s. XV, British Library)

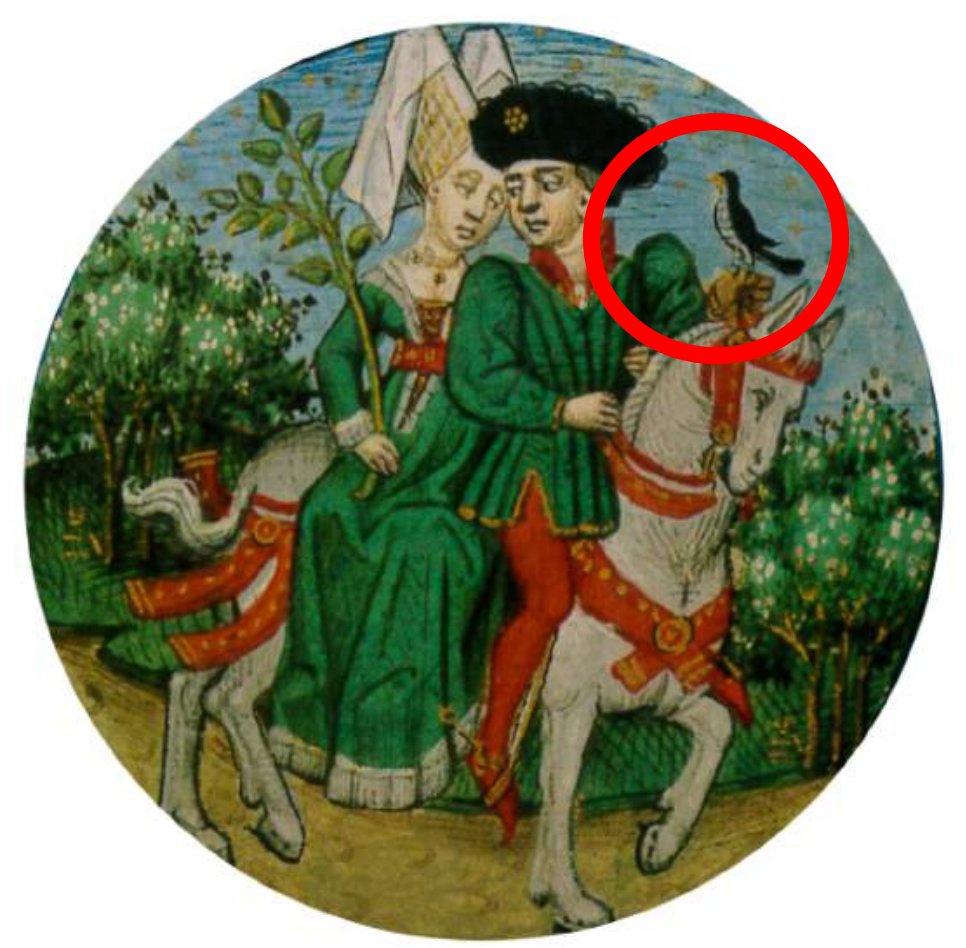

Ms 2019, fol. 5 (s. XV, British Library)

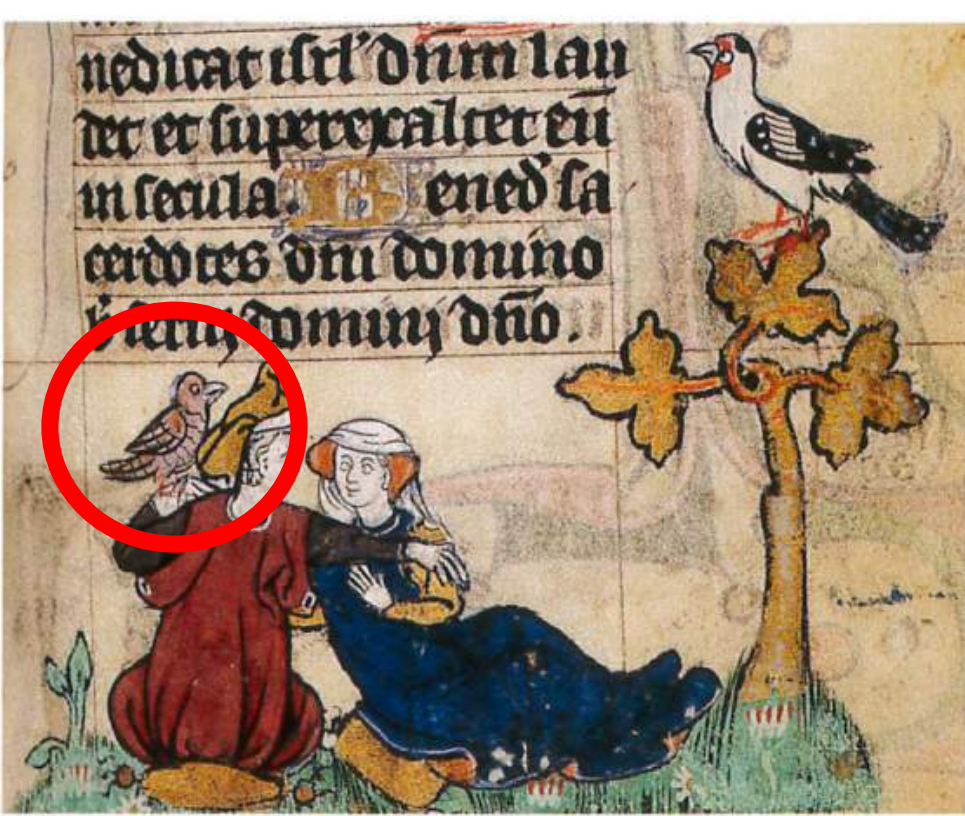

Ms 17, fol. 59 (ca. 1300, British Library) 


\section{Análisis iconográfico de la portada (Sevilla, 1501)}

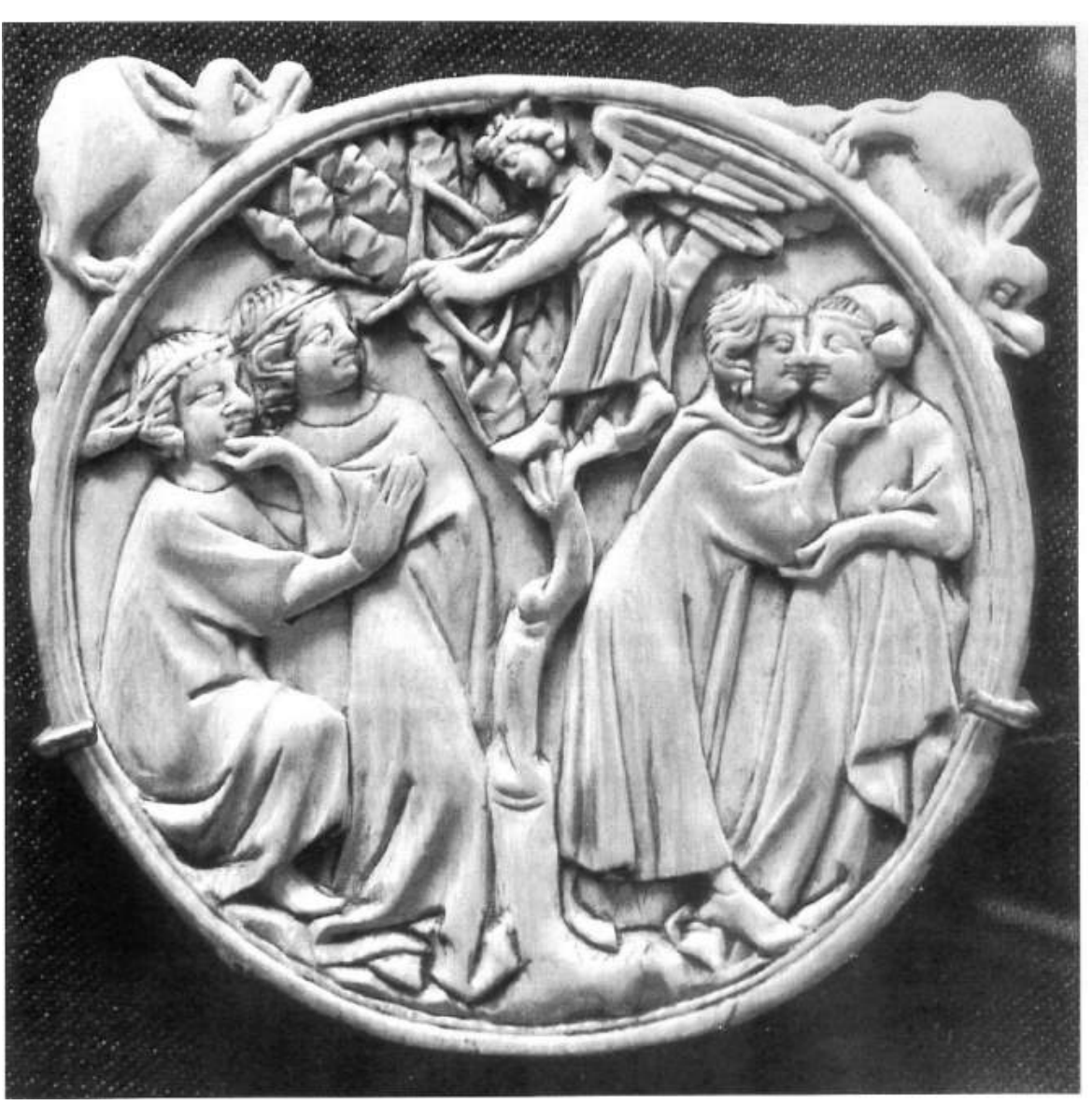

Ivoire, s. XIV. Museo de Cluny (cit. Garnier, II, 1982, p. 406407).

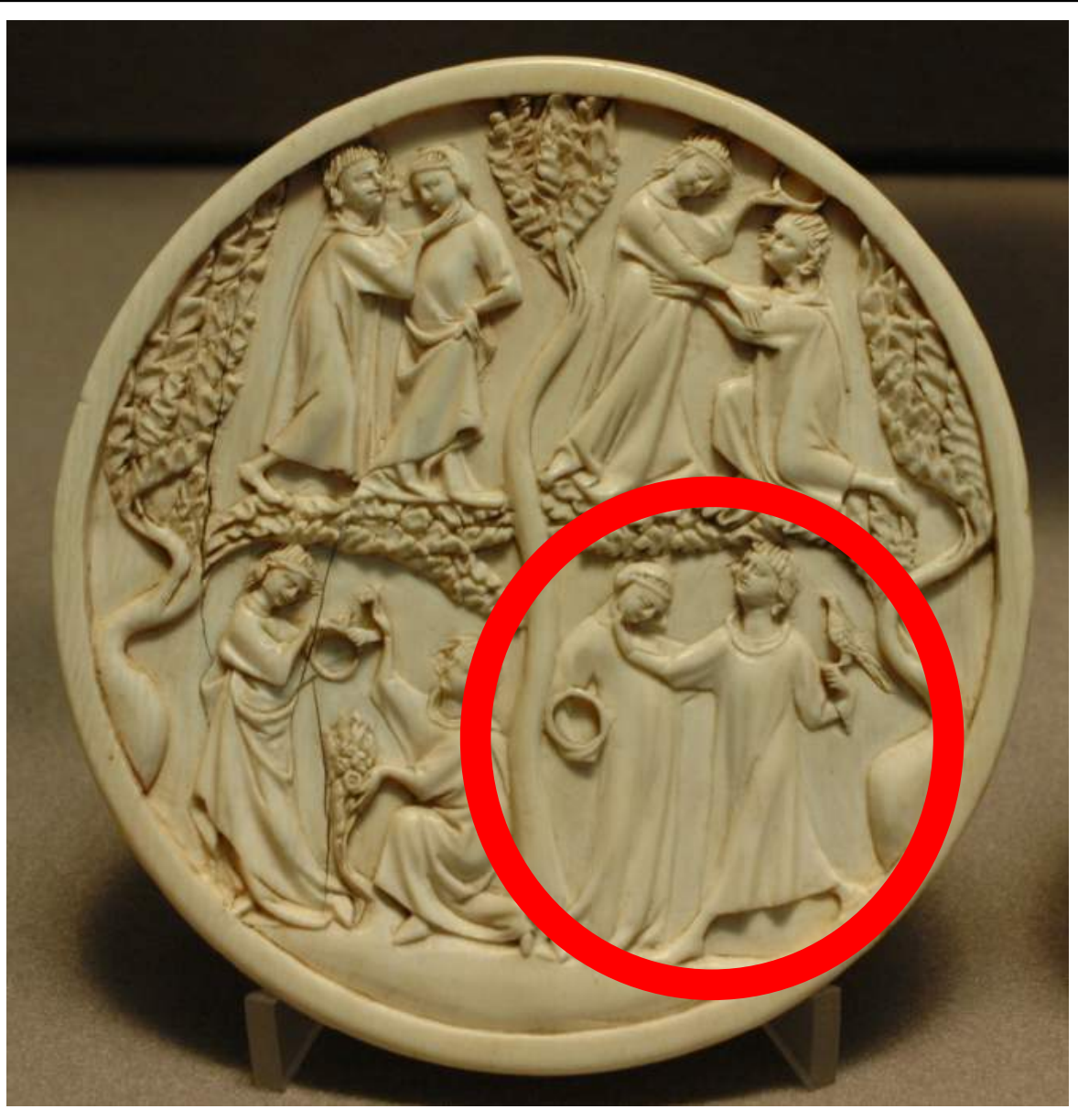

Ms 2019, fol. 5 (s. XV, British Library) 


\section{Análisis iconográfico de la portada (Sevilla, 1501)}

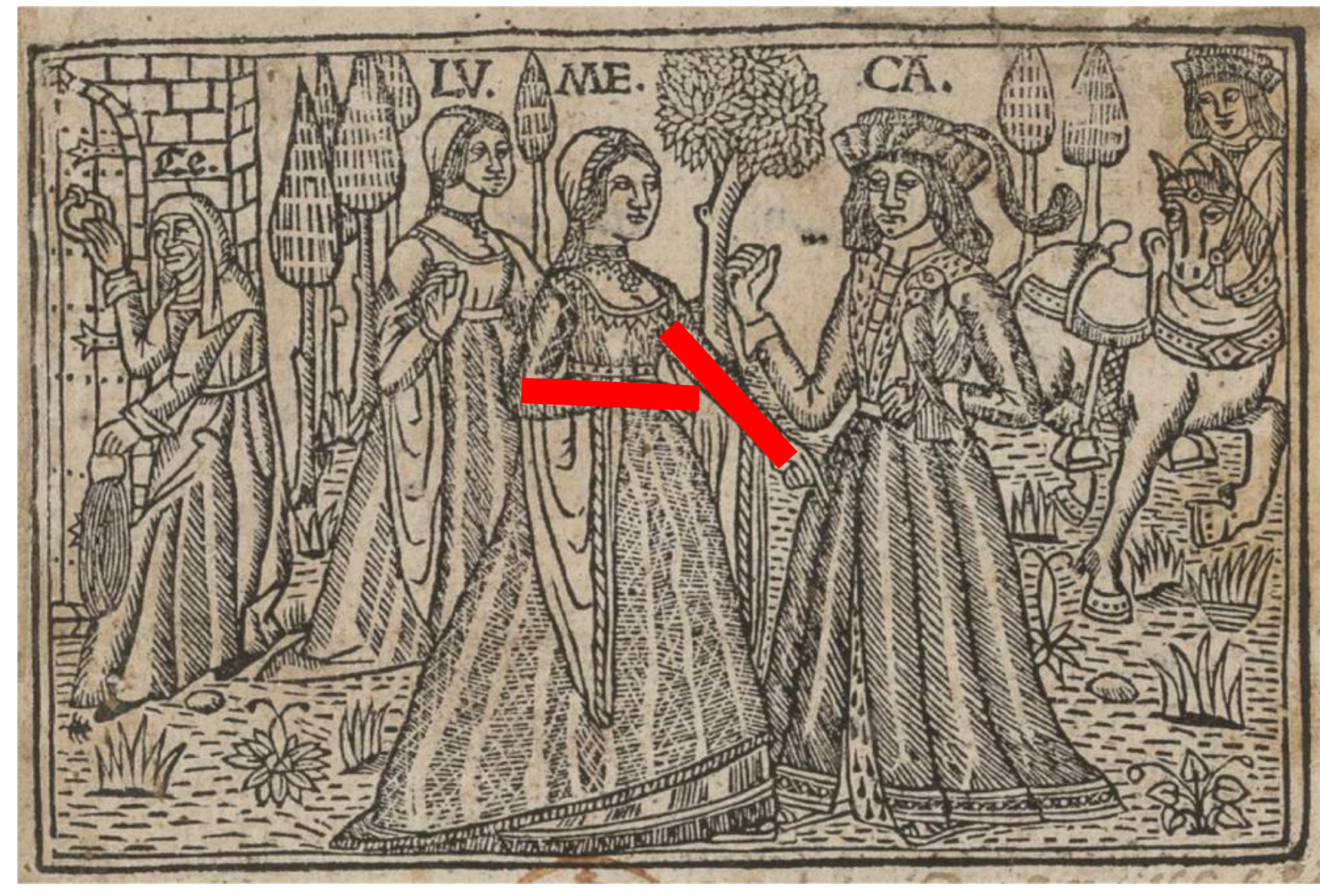

Sevilla: Estanislao Polono, 1501 


\section{Análisis iconográfico de la portada (Sevilla, 1501)}

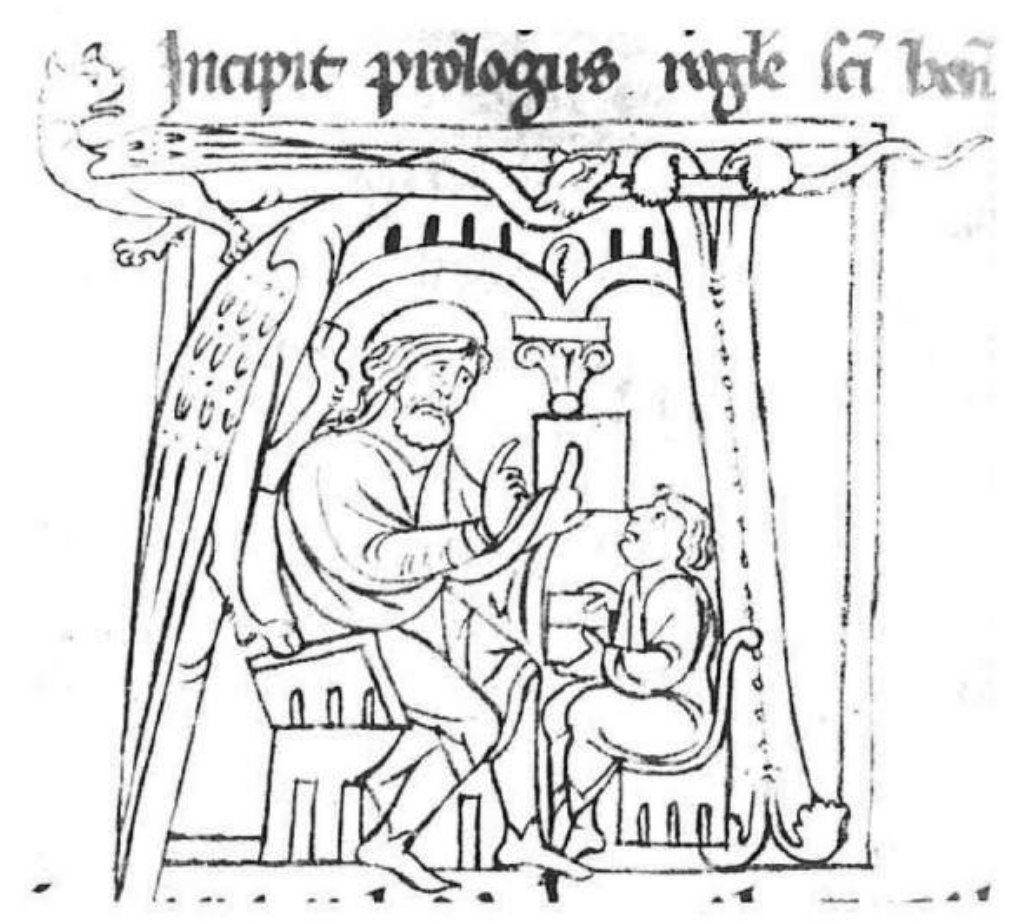

Règle de saint Benoît avec le commentaire de Smaragde, XII siècle. Le Mans, bibl. mun., ms. 349, fol. 2v (cit. Garnier, I, 1982, p. 31-34)

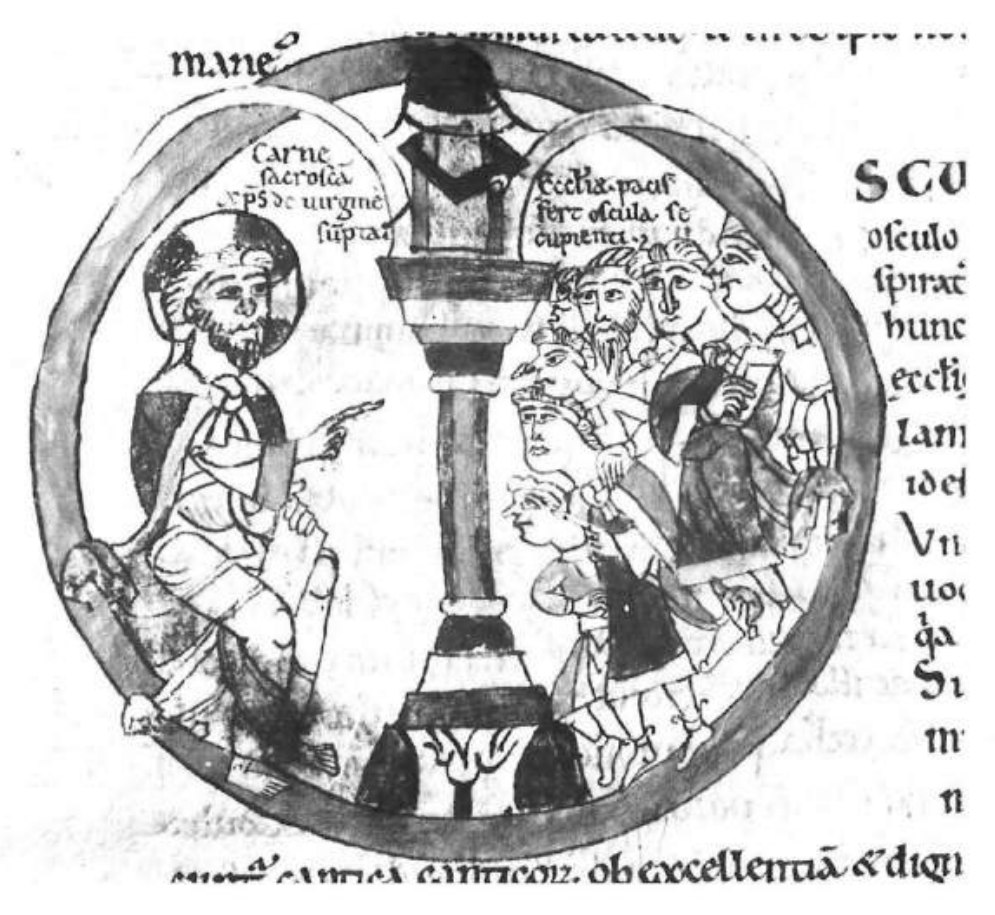

Le Christ, l'église et les Chrétiens Initiale du Cantique des Cantiques Osculetur me osculo orís sui, Bède, Commentaire sur le Cantique des Cantiques. Le Mans, bibl. mun., ms. 20, fol. 86v (cit. Garnier, I, 1982, p. 4) 


\section{Propuesta de análisis iconológico de la portada (Sevilla, 1501)}

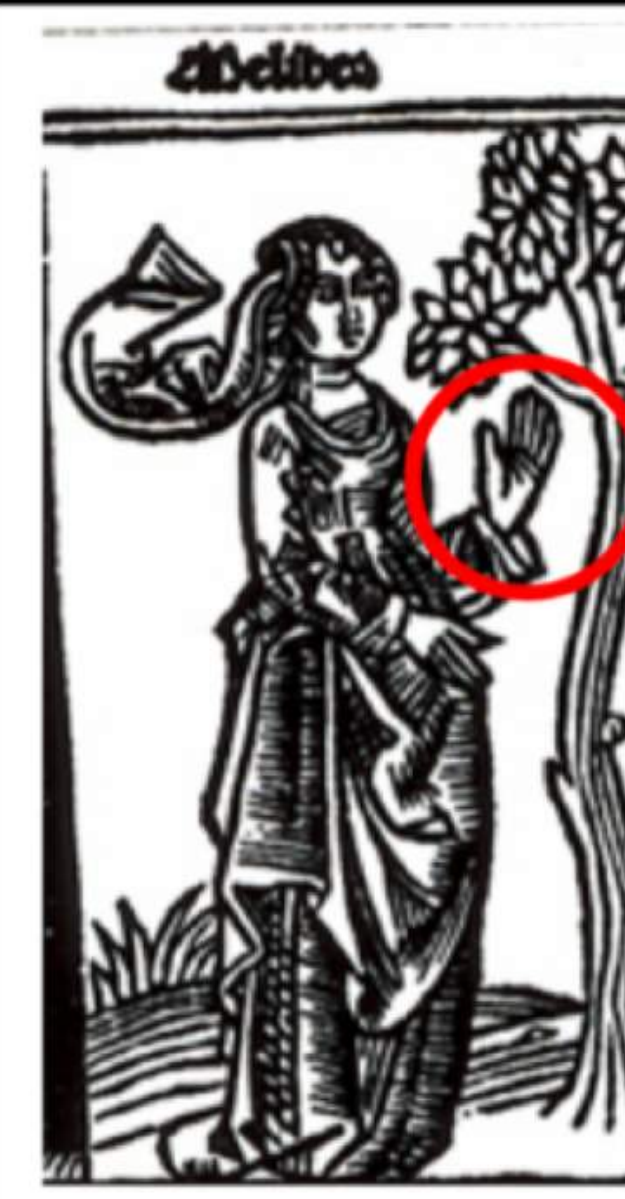

Burgos: Fadrique de Basilea, 1499?

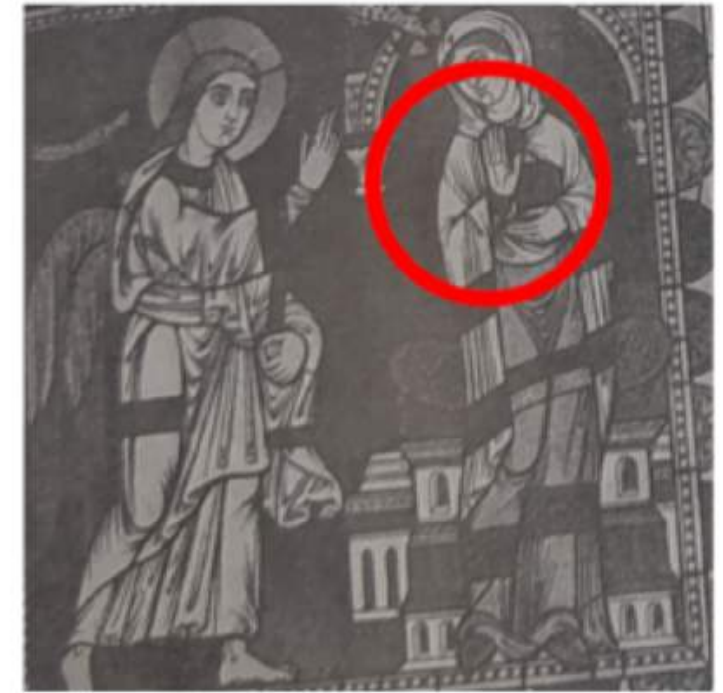

Anunciación. Fragmento de una vitrina del siglo XII. Chartres. (cit. Mâle, 1931)

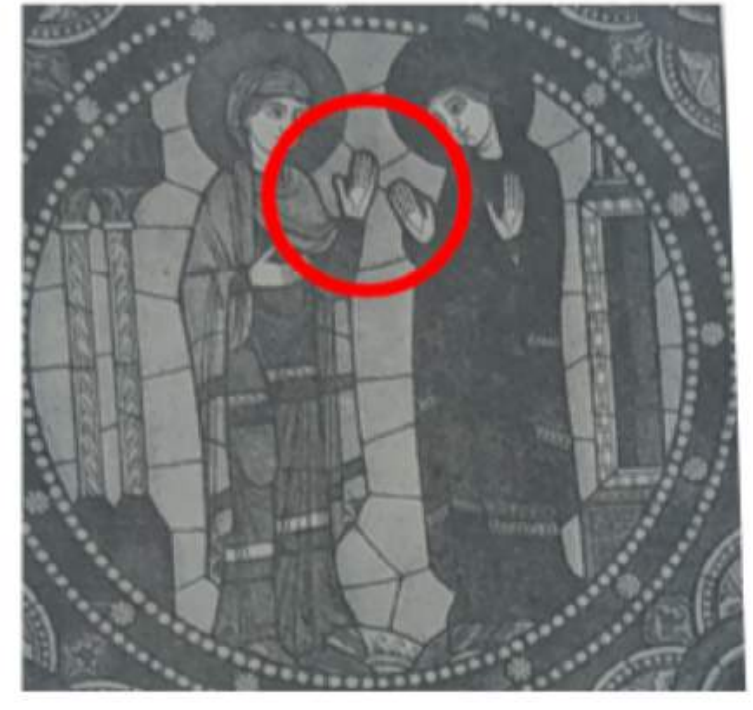

Visitación. Fragmento de una vitrina del siglo XIII.

Chartres. (cit. Mâle, 1931) 


\section{Propuesta de análisis iconológico de la portada (Sevilla, 1501)}

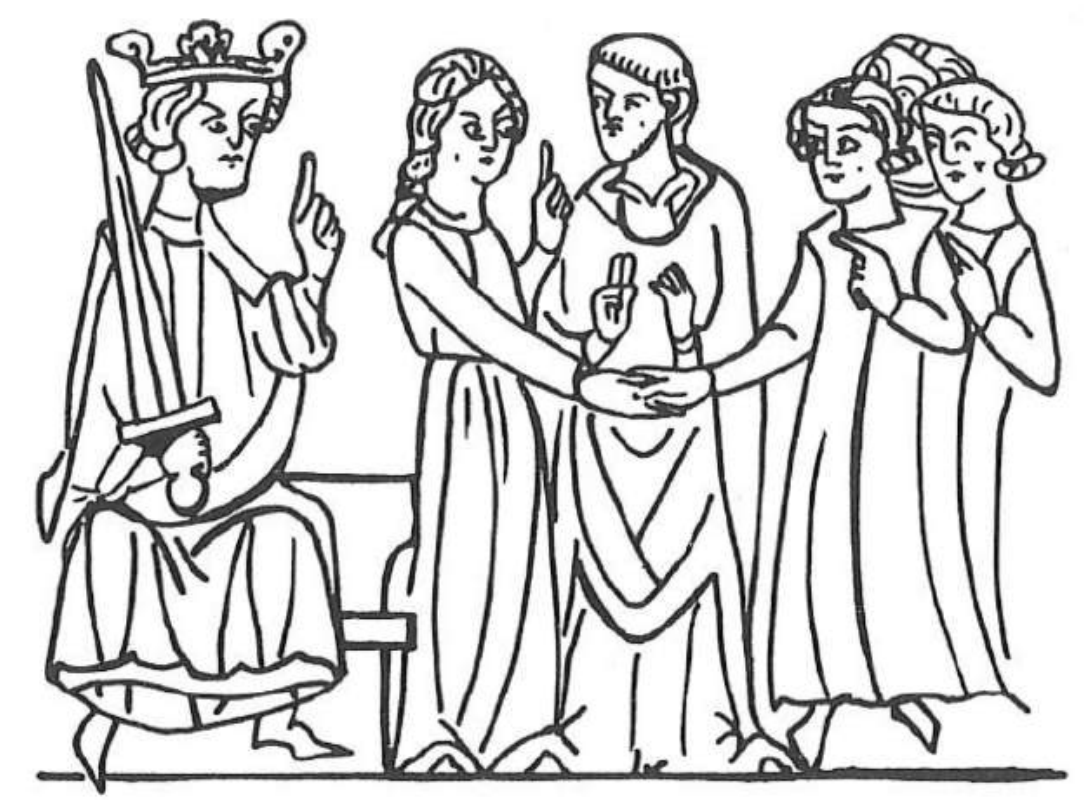

Boda. Código Justiniano. Traducción francesa de principios del siglo XIV. Orléans, bibl. mun., ms. 392, fol 66v (cit. Garnier, II, 1982, p. 42).

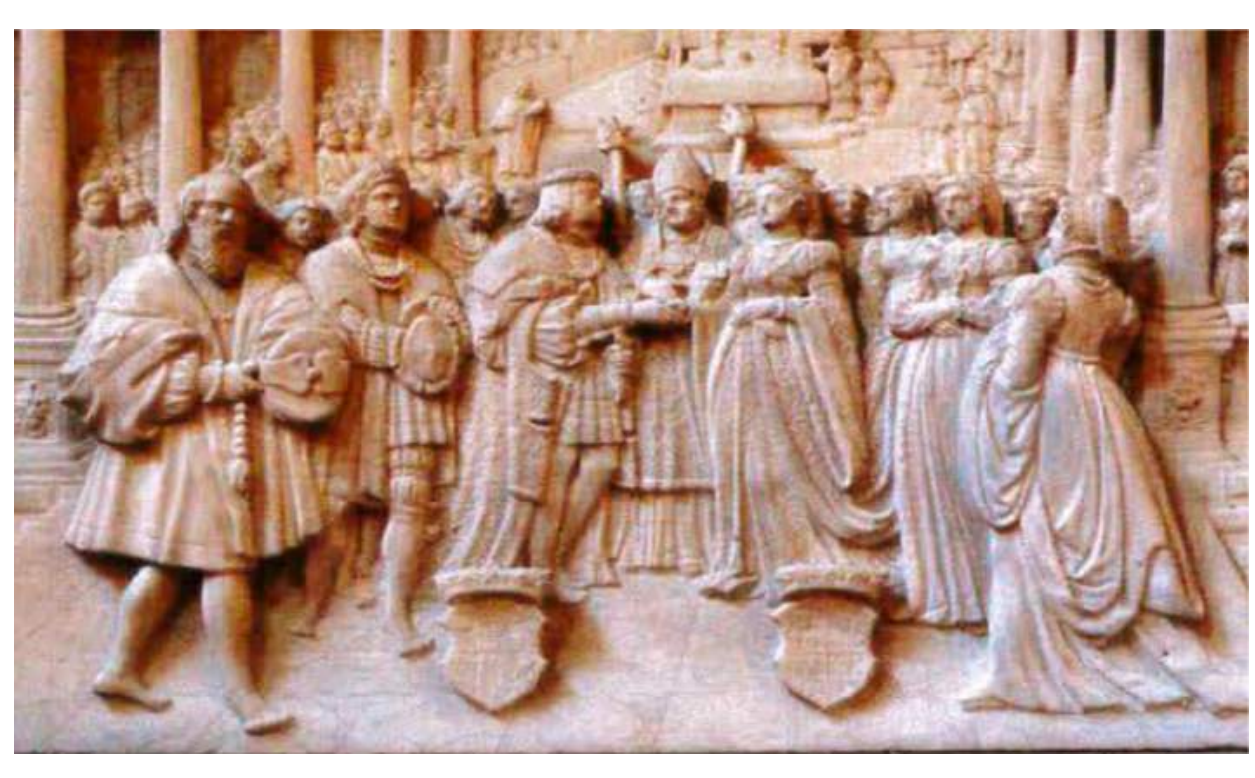

Detalle de Boda de Maximiliano y María de Borgoña en Gante, Tumba de Maximiliano, siglo XVI. Hofkirche, Innscruck (cit. Rodríguez Moya y Mínguez, 2013, p. 110) 


\section{Propuesta de análisis iconológico de la portada (Sevilla, 1501)}
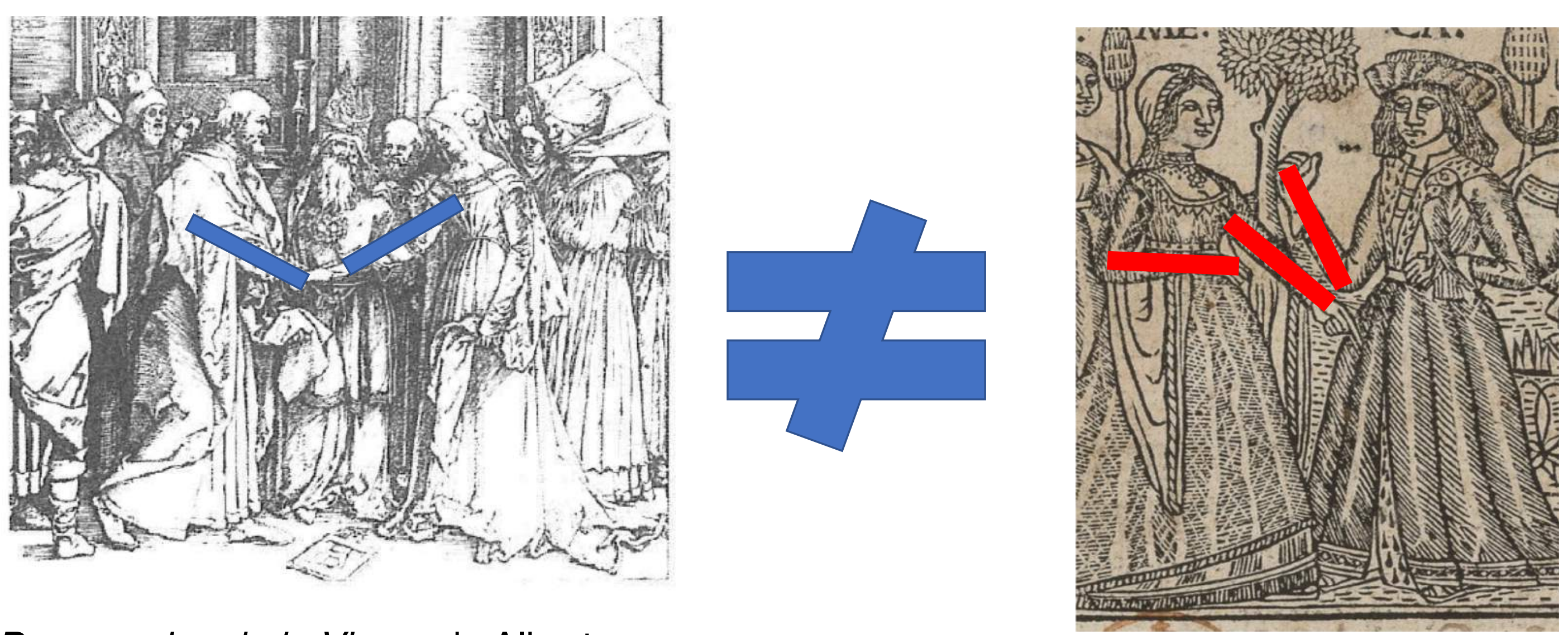

Desposorios de la Virgen de Alberto

durero, 1503-1511, Biblioteca

Nacional de España, Madrid. 


\section{Conclusiones}

Gran parte del éxito de las ediciones sevillanas residió en la acertada composición iconográfica de su portada y en aunar, frente a una tradición más clásica (terenciana) como la burgalesa, diferentes elementos propios de la cultura visual del momento como lo fueron:

- Los parámetros cortesanos.

- La disposición similar al esquema compositivo de la iuntio dextrorum. 


\title{
Muchas gracias
}

\author{
amjimenez@unizar.es
}

Congreso Virtual CELPYC

4 y 5 de junio de 2020 